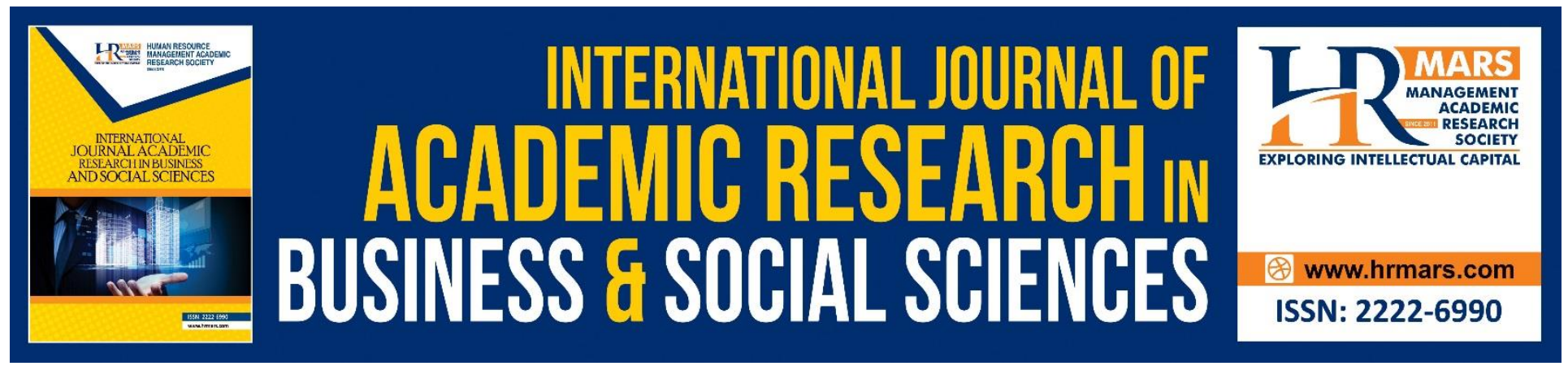

\title{
The Relationship between Environmental Performance and Corporate Governance towards Environmental Disclosure of Oil and Gas Companies Operating in Malaysia Upstream
} Projects

\section{Safarina Abdul Ghani, Diana Rosdi}

To Link this Article: http://dx.doi.org/10.6007/IJARBSS/v9-i3/5706

DOI: $\quad 10.6007 /$ IJARBSS/v9-i3/5706

Received: 19 Feb 2019, Revised: 26 March 2019, Accepted: 30 March 2019

Published Online: 03 April 2019

In-Text Citation: (Ghani \& Rosdi, 2019)

To Cite this Article: Ghani, S. A., \& Rosdi, D. (2019). The Relationship between Environmental Performance and Corporate Governance towards Environmental Disclosure of Oil and Gas Companies Operating in Malaysia Upstream Projects. International Journal of Academic Research in Business and Social Sciences, 9(3), 460475.

\section{Copyright: (C) 2019 The Author(s)}

Published by Human Resource Management Academic Research Society (www.hrmars.com)

This article is published under the Creative Commons Attribution (CC BY 4.0) license. Anyone may reproduce, distribute, translate and create derivative works of this article (for both commercial and non-commercial purposes), subject to full attribution to the original publication and authors. The full terms of this license may be seen

at: http://creativecommons.org/licences/by/4.0/legalcode

Vol. 9, No. 3, 2019, Pg. 460 - 475

http://hrmars.com/index.php/pages/detail/IJARBSS

JOURNAL HOMEPAGE

Full Terms \& Conditions of access and use can be found at http://hrmars.com/index.php/pages/detail/publication-ethics 


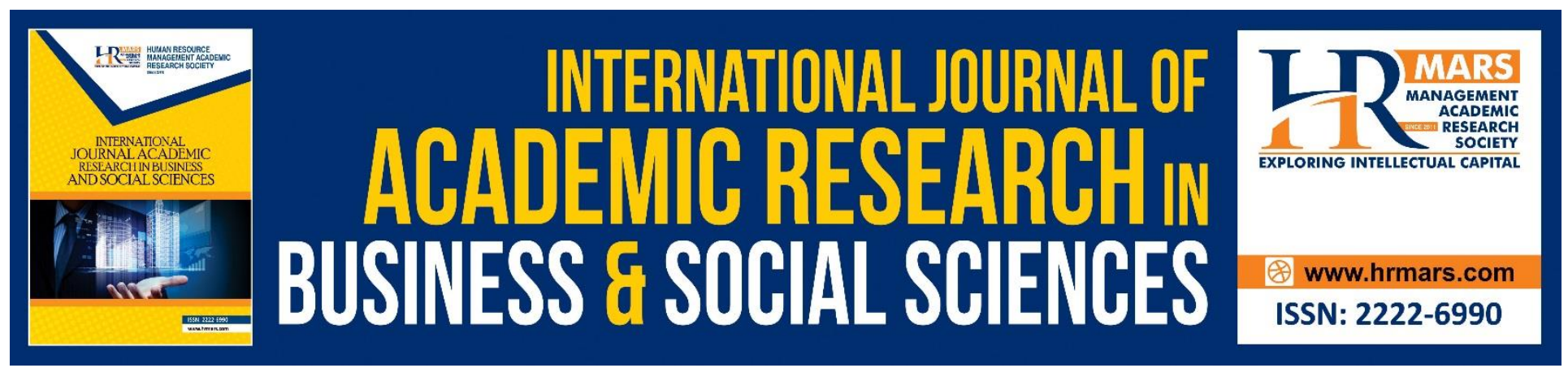

\title{
The Relationship between Environmental Performance and Corporate Governance towards Environmental Disclosure of Oil and Gas Companies Operating in Malaysia Upstream Projects
}

\author{
Safarina Abdul Ghani \\ Faculty of Business \& Information Science, UCSI University, Terengganu Campus, Marang, \\ Terengganu, Malaysia

\section{Diana Rosdi} \\ Faculty of Business \& Information Science, UCSI University, Terengganu Campus, Marang, \\ Terengganu, Malaysia
}

\begin{abstract}
Environmental disclosures have increased in recent years as the concerns on global environmental issues have been growing. As the activities of oil and gas industry deals with destructive operations, it is one of the industry which is considered as the most exposed industry to environmental matters which owes effort to be responsible in disclosing the information about the activities and maintain sustainable developments. This research is to investigate and explore the relationships of environmental performance and corporate governance towards the environmental disclosure of oil and gas companies operating in the upstream projects in Malaysia by adopting the Global Reporting Initiative (GRI) index. This study will apply an interpretative approach to social science research by using content analysis based on secondary data extracted from annual reports, sustainability reports, corporate social responsibility reports as well as companies' website. The research will be conducted on 54 annual reports of 27 oil and gas companies operating in Ma laysia upstream projects from 2015 to 2016. Regression analysis and correlation will be used to examine the association between the variables of this research study. It is expected that there is a significant relationship of environmental performance and corporate governance towards the environmental disclosure. This study aspires to contribute to valuable knowledge which would suggest and outline the best practices for companies in disclosing their environmental disclosures.

Keywords: Environmental Performance; Corporate Governance; Environmental disclosure; GRI Index
\end{abstract}




\section{Introduction}

The oil and gas industry has become the main industry and main contributor to the economies of countries in the world. However, the activities of oil and gas hold many major potential hazards to the environment and thus the environmental concerns are increasing over the recent years due to the impact of the rapid oil and gas activities around the world. Due to the occurrence of incidents related to the environment as a result from the impacts caused by activities done by companies especially oil and gas companies, this has contributed to the increment of awareness on environmental across many countries over the world, including Malaysia as the developing country (Eljayash, James, \& Kong, 2012). Malaysia is shifting towards environmental degradation which resulted from the challenges of environmental issues due to rapid urbanization and the effort to pursue better life quality. Therefore, through the help of environmental information, the business decisions' impact on the environment could be recognized by the society and firms (Milne \& Patten, 2002).

In recent years, most have realized that the environment is the biggest asset to be managed and sustained in which the environmental reporting is pertinent (Sulaiman, Abdullah, \& Fatima, 2014). Besides, in demonstrating the degree in which the companies are attaining their responsibilities to the environment, it could be seen that the demand is increased for the firms in disclosing more information which is relevant to their performances due that the general becoming more concern about the environment (Cho, Roberts, \& Patten, 2010). The government of many countries around the world as well has been regulating and adapting laws which are necessary to protect the environment at the same time the impact of economic activities on the environment is being controlled. In Malaysia, the annual reports are to be disclosed by the companies listed in the Malaysian Stock Exchange (Bursa Malaysia).

The association between environmental information and the potential of the firm's environmental performance is one of the most important issues which affect the firm's environmental disclosure (Clarkson, Li, Richardson, \& Vasvari, 2008). The key issues relating to the environmental matters and the impact towards the companies' future performance and position, the uncertainties and risks, and policies on the environmental issues that are significant such as the emissions trading should be included in the environmental disclosures (latridis, 2012). The effects of greenhouse gas emissions are demonstrated to have significant impact on the global warming (Stern, 2006). The reporting of greenhouse gas emissions should be included under the emissions trading as the major impact from the oil and gas activities which is the greenhouse effects caused by greenhouse gas emissions. In this era, the greenhouse gas (GHG) emissions is one of the main threats which give impact to the globalization due to the increased in the GHG level of concentration on the atmosphere and the earth's surface. This has caused many adverse effects to the environment (Liu, et al., 2015).

Companies are exerted by the pressure of their stakeholders such as their shareholders as well as the consumers in decreasing the GHG emissions (Jeswani, Wehrmeyer, \& Mulugetta, 2007). Thus, according to L.Luo \& Q.Tang (Luo \& Tang, 2014), "It is expected that the companies would play their vital role to reduce the GHG emissions in order to stabilize the change in the climate". This can be concluded that the GHG emissions is the major contributor to the pollution and create the most impacts on the environment. The companies are facing the increased in demand in disseminating more information in their environmental disclosure relevant to their actual performances in order to 
show their environmental concerns (Meng, Zeng, Shi, Qi, \& Zhang, 2014). The developments of environmental disclosures have been associated with the higher tendency of companies in disclosing the information on their environmental performance and they may disclose more to demonstrate to their shareholders that they are relatively good environmental performers (Braam, de Weerd, Hauck , \& Huijbregts, 2015).

One of the global policy network which has emerged as a guideline for environmental disclosure by companies around the world concerning on sustainability is the Global Reporting Initiative (GRI) (Massie, 2001). The association between environmental performance and environmental disclosure have been examined by many researchers related to various mechanisms of environmental performance.

In other hand, the corporate governance issues in the recent years and its relation within the environmental aspect has been growing in interest (Cuesta \& Valor, 2013). Better corporate governance and accountability trends have become the focused attention which the organizations have for their greater responsibilities towards the stakeholders, the environment and the society which they operate (ACCA, 2004). The association between corporate governance and environmental disclosure have been examined by many researchers related to the various aspects of corporate governance for example the board size, board composition, board gender and so on (Brammer \& Pavelin, 2006). In recent days, the concerns about corporate environmental management are growing due to the arisen environmental issues. Environmental reporting and disclosure has become mainstream and prevailing practice by many companies in the world due to the growing concern on environmental matters including in Malaysia. Besides, the government is also adapting and enacting laws which are necessary to protect the environment and takes control on the environmental impacts of economic activity across the nation.

The performance of companies in term of environmental impact from their activities are also being questioned by social movements. The accountability of the companies' decisions has been influenced by these forces and also in response to the demand of social to manage the negative environmental impacts on biodiversity, climate and human health which are caused by economic activities. Therefore, the transparency of environmental is important at international level (da Rosa, Lunkes, Hein, Vogt, \& Degenhart, 2014).

One of the five most polluting industries is the oil and gas industry (Clarkson, Li, Richardson, \& Vasvari, 2008). In the last decade, a rapid growth is seen in the use of annual report as well as independence reports such as sustainability report in disclosing the social and environmental performance of companies. The concerns are arisen regarding not only the quality of the reported information by companies but also the consequences of activities done by companies on both the society and environment even though these reports are considered to be important in evaluating legitimacy of the disclosures by companies (Cho, Michelon, \& Patten, 2012).

A company needs to disclose material information to their stakeholders according to the GRI guidelines but the company may decide which indicators to be used as the material for its specific business which makes it differ from the stakeholder's point of view. It is shown in the academic studies that the industries with greater risk of environmental impacts will show a greater adoption to the GRI guidelines (Alonso-Almeida, Llach, \& Marimon, 2013). Under the oil and gas industry, the issues regarding environment has becoming the main focus as an industry will exert more efforts into 
impacts of material which are related to its operating activities (Noronha, Tou, Cynthia, \& Guan, 2012). In Malaysia, Bursa Malaysia plays an important role in enhancing the transparency of the corporate environmental information, corporate governance related issues as well as social issues among companies in Malaysia. Bursa Malaysia launched a new Sustainability Framework in October 2015 and has developed a Sustainability Reporting Guide which is aiming to assist the listed issuers in improving the sustainability-related disclosures in order to meet the gradual information needs by various stakeholders. This new framework is aligned with the international reporting frameworks GRI Guidelines. Bursa Malaysia has demonstrated its commitment to the sustainability by having the listed companies to disclose their narrative statement on their materials of economic, environmental and social (EES) in their annual reports (Malaysia PLC, 2017). Although the environmental disclosures by the companies increases, it is questionable how much the companies actually disclose relevant environmental information and what are the factors which affect the disclosure.

The aim of this study is to identify the relationships between environmental performance and corporate governance in the annual reports of oil and gas companies which involved in Malaysia upstream projects with the use of the latest GRI disclosure index as a benchmark. This topic is interesting to be studied due to the environmental issues occurred globally which affect the society and the trend of environmental reporting which is growing. Further, this study contributes to the academic discussion which focusing more on the non-financial aspects in the environmental disclosure. This could be a significant contribution to the area of knowledge since the prior studies discussed thoroughly only on the financial area.

This study will collect the data from the annual reports, sustainability reports and CSR reports as well as from the websites which the companies published on their environmental disclosure.

Further, the chosen companies have to present their environmental disclosures following the GRI index for the year 2015 and 2016. Some of the oil and gas companies listed under Malaysia Oil \& Gas Report Quarter 12016 would be excluded due that not all of the companies present their environmental disclosure by using GRI index. The research period is limited to a 2-year period due to the reason that Bursa Malaysia has just launched the Sustainability Reporting Framework in 2015 having the GRI index as the guidelines, which means the companies are yet actively practicing it.

\section{Literature Review}

The upstream sector is a part of the oil and gas industry which is responsible for exploration activities and producing the crude oil and natural gas deposits. The most dangerous and widespread impact of the activities done by oil and gas industry within this context is pollution and it is associated with almost all activities throughout all phases of oil and gas activities from exploratory to refining, especially the upstream sector. The amount of over 800 different chemicals from the wastewaters, hazardous waste and gas emissions which are generated during the upstream activities of drilling, production, refining and transportation. The greenhouse effect is among the other environmental impacts from oil and gas activities (Mariano \& La Rovere, 2007). In Malaysia, the oil and gas industry contributes significantly to the economy of Malaysia and Malaysia is one the largest exporter for LNG in the world (The Malaysian Oil \& Gas Industry, 2016). The upstream sector of Malaysian oil and gas industry have been focused on the development activities since the 1960s with the oil and gas fields being built upon off the Peninsular Malaysia and Sarawak (Malaysia Upstream Summary, 2017), in 
which PETRONAS being the national oil company and as the main driver of upstream-related activities.

The mechanism for communication which the companies use in order to meet the pressure from the external as well as in adapting to the norms which are socially accepted defined the environmental disclosure (Mobus, 2005). There are some factors which lead the companies in disclosing about their environmental information. The related information for the environmental disclosure could be found from the companies' annual reports, sustainability reports, and CSR reports in which it is measured by using the GRI index (Clarkson, Li, Richardson, \& Vasvari, 2008). In Malaysia, there is requirement from the Malaysian Environmental Quality Act 1977 which the companies are currently using as the guidelines to manage and disclose their environmental sustainability. The requirement from the Act is only a principle of guiding the companies in establish the disclosure despite the information to be disclosed is depending on the company's decision itself.

Due to increasing concerns on the environmental issues, the public has been expecting that the organizations to improve their commitments and focus on their environmental performance which indicate how the organizations effectively concern and taking care of their responsibilities towards the environment (Gummerus, 2015). The corporate governance issues have been highlighted in recent years around the world due to its importance. Besides, due to the increasing amount of research on corporate governance over the recent years has led to a greater variation of definition of the corporate governance. Among the dimensions of the corporate governance include the board size, board diversity, board independence and managerial ownership (Elsayih, 2015). Corporate governance is defined as the system for checking and balancing in both the external and internal to the companies in ensuring the companies to discharge their accountabilities and responsibilities towards their stakeholders and to act in a socially manner in all of their business activities areas (Solomon, 2013).

Based on the voluntary disclosure literature, it indicates that the companies are preferred to report good news rather than disclosing bad news (latridis, 2013). The voluntary disclosure explains the reasons on why the firms make disclosure at different level (Bewley \& Li, 2000). Based on the voluntary disclosure theory, the companies tend to only disclose about corporate information if only they are certain that their environmental performance is good. Therefore, the companies with better or superior environmental performance tend to voluntarily disclose on their corporate information to distinguish themselves from the poor performers (Verrechia, 1983); (Dye, 1985). In addition, the stakeholder theory also supports the relationship in which according to stakeholder theory, environmental disclosure aids the companies in communicating about their environmental aspects from their business activities. The more important the stakeholders to the company, the more efforts will be exerted by the company to manage and manipulate the relationship by using environmental disclosure as a way to convey on their environmental performance. The relationship between environmental performance and environmental disclosure have been approached by prior studies with various theoretical perspectives and having mixed results. According to Patten (Patten, 2002) , there are however concerns on the measurement and methods which are argued in bringing the findings into question. There is a positive relationship between the environmental performance and environmental disclosure which was examined by Clarkson (Clarkson, Li, Richardson, \& Vasvari, 2008) as implied by the voluntary disclosure theory where a more rigorous research design was being used. 
In specific, it was examined that the good environmental performers disclose more on their environmental information. However, this result is in contrast with numerous of prior studies where there were negative relationship (Brown \& Deegan, 1998); (Patten, 2002) as the socio-political theory is implied. Thus, even though there were previous researches that provide evidence which the voluntary disclosure theory is robust to support the relationship, it is still arguable as an unresolved issue in the literature (Clarkson, Li, Richardson, \& Vasvari, 2008). Therefore, the hypothesis which is presented from both theoretical perspectives and in alternate form is then developed:

$H_{0}$ : Environmental disclosure is positively associated with environmental performance. $H_{1}$ : Environmental disclosure is negatively associated with environmental performance.

Various mechanisms of corporate governance have been used in examining the relationship between corporate governance and environmental disclosure. Environmental disclosures that are effective would tend in closing the gap of information between managers, stakeholders and shareholders. In this research study, the corporate governance mechanisms which are used are the existence of environmental committee in the board of directors and the board size. The background and qualifications of the directors is argued to have a major factor which influence the corporate governance of an organization, in this case is the existence of the environmental committee in the board of directors. The existence of environmental committee within board of directors would increase the importance given to the particular perspective of the corporate governance system and as a result will lead to an increase of environmental disclosure by the company (lonel-Alina, Emila, \& Mariaa, 2012). In addition, the existence of the environmental committees in the board of directors can determine their approach as being reactive or proactive towards the environmental disclosure (Peters \& Romi, 2015). Previous literature assumed that the board size determines the efficacy and efficiency of the corporate governance thus affecting the decisions and disclosure about the corporate information (Xie, Davidson III, \& DaDalt, 2003) and a larger board of directors tend to attract more experienced individuals. There have been conflicting opinions on the size of the board directors which are appropriate. One side of the opinions argued and suggested that the larger the board size will tend to increase the quality of the decision-making by employing the diversified knowledge and expertise in the board of directors (Laksmana, 2010); (Bonn, 2004). The other side of the opinion argued that the smaller sized board of directors having more consideration and more effective to achieve a collective decisions as well as in monitoring the actions by the management (Lakhal, 2005); (Cheng S. , 2008). With regard to the different results on the relationship between board size and environmental performance, some recent studies have found a positive and significant relationship between the variables (Rao, Tilt, \& Lester, 2012). Nevertheless, there are also prior studies that have proven that there is no relationship between the board size and the environmental disclosure (Halme \& Huse, 1997); (Cheng \& Courtenay, 2006). The companies with effective corporate governance mechanisms are expected to have more environmental disclosure. The hypothesis then is developed as follows:

\section{$H_{0}$ : There is a positive relationship between the environmental disclosure and the corporate governance.}


INTERNATIONAL JOURNAL OF ACADEMIC RESEARCH IN BUSINESS AND SOCIAL SCIENCES

Vol. 9, No. 3, March, 2019, E-ISSN: 222 2-6990 ¿ 2019 HRMARS

$\mathrm{H}_{2}$ : There is a negative relationship between the environmental disclosure and the corporate governance.

\section{Conceptual Framework}

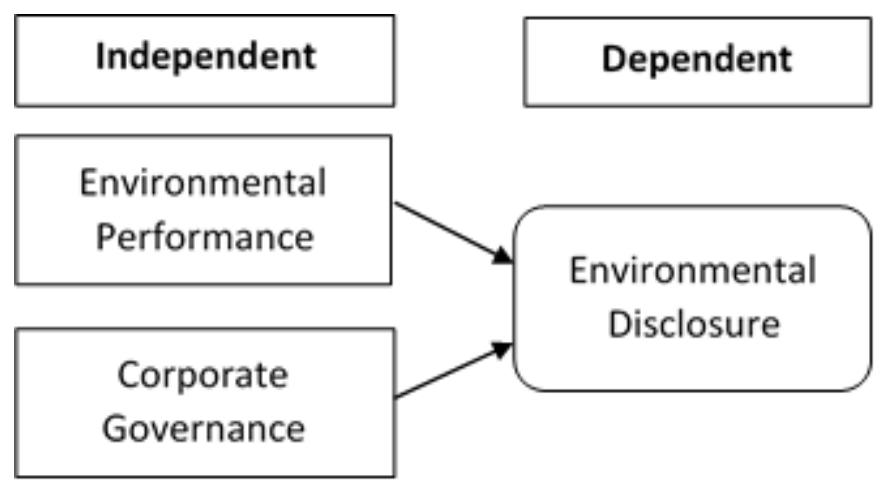

Fig. 1: The Relationship of Dependent Variable and Independent Variables

\section{Discussion}

This research is a quantitative method which will be conducted using the secondary data obtained from the annual report is the main source, with support of sustainability reports and CSR reports that will be gathered based on the oil and gas companies selected from the Malaysia Oil and Gas Report 2016 Quarter 1 following the GRI disclosure index. A total of 54 annual reports selected from 27 oil and gas companies operating in Malaysia upstream projects from 2015 to 2016. This study adopted content analysis to examine the disclosures of dependent variable and independent variables mechanisms. Through the procedures of content analysis, the reliability for the measurement will be tested as the measurement of the disclosures is required to be ascertained and the validity test is required as an assessment to strengthen the applicability of the disclosure. Regression analysis and correlation coefficient will be used in this study to analyze the relationships between environmental performance and corporate governance with environmental disclosure. This study is expected to give positive relationships for both environmental performance and corporate governance towards the environmental disclosure.

This study will examine the relationship between the environmental disclosure with environmental performance which includes the mechanisms of GHG emissions and pollution management, and with corporate governance which includes the existence of environmental committee and board size of the selected oil and gas companies. For the first model of the independent variable which is the environmental performance, GHG emission and pollution disclosure information are predicted to have association with the environmental disclosure. For the second model of the independent variable which is the corporate governance, the existence of environmental committee and board size are predicted to have association with the environmental disclosure. Therefore, the following formulas are developed for the relationships. 
INTERNATIONAL JOURNAL OF ACADEMIC RESEARCH IN BUSINESS AND SOCIAL SCIENCES

Vol. 9, No. 3, March, 2019, E-ISSN: 2222-6990 @ 2019 HRMARS

Environmental Performance and Environmental Disclosure: (1) Environmental Disclosure $=f$ [GHG emissions + pollution]

Corporate Governance and Environmental Disclosure: (2) Environmental Disclosure $=f$ [Existence of environmental committee + board size]

In addition, another model for is developed for the combination of environmental performance and corporate governance towards the environmental disclosure. The following formula is developed. Environmental Performance and Corporate Governance towards Environmental Disclosure: (3) Environmental Disclosure $=f[(G H G$ emissions + pollution $)+($ Existence of environmental committee + board size)]

This study will use different index for different variables due to different nature. For the dependent variable, a disclosure index checklist adopted from Eltaib (Aburaya, Rania, \& Kamal, 2012) and Choi, D.Lee, \& J.Psaros (Eltaib, 2012) based on GRI guidelines will be used, refer to the Figure 2 for the checklist constructed. For the independent variable, environmental performance GHG emissions disclosure checklist adopted from (Choi, Lee, \& Psaros, 2013) and Pollution disclosure checklist adopted from (Sulaiman, Abdullah, \& Fatima, 2014); (Bae Choi, 2013) will be used. Figure 3 is for GHG emissions disclosure checklist and Figure 4 is for Pollution disclosure checklist. While for the independent variable, corporate governance will be measured as the Figure 5.

A preliminary study will be conducted in order to investigate the relationship between environmental performance and corporate governance towards environmental disclosure of oil and gas companies operating in Malaysia upstream projects. As been mentioned previously, the instrumentation has been developed as a tool in measuring the relationship of dependent variable and independent variables. This pilot study is very important in determining the applicability of the checklist towards the environmental themes in the annual reports. On the other hand, this pilot study will aid the researcher in assuring the reliability and validity of the established measurement. Lastly, the results of the pilot study are believed to help the researcher in aligning the current measurement of this study with the actual practice in the industry. 


\section{INTERNATIONAL JOURNAL OF ACADEMIC RESEARCH IN BUSINESS AND SOCIAL SCIENCES Vol. 9, No. 3, March, 2019, E-ISSN: 222 2-6990 (C) 2019 HRMARS}

\begin{tabular}{|c|c|}
\hline & Environmental Disclosure Checklist \\
\hline No. & Categories \\
\hline 1 & General environmental disclosure \\
\hline G1 & $\begin{array}{l}\text { 1.1 Environmental policies, concerns and any general mention to the environment and climate change } \\
\text { - Actual statement of environmental policies } \\
\text { - The positions or departments for the environmental and/or safety management } \\
\text { - Energy saving and conservation } \\
\text { - Health and safety policies } \\
\text { - Environmental investment and appraisal on investment }\end{array}$ \\
\hline $\mathrm{G} 2$ & $\begin{array}{l}\text { 1.2 Compliance with Environmental Laws and Standards } \\
\text { - Mention on the environmental regulations and requirements } \\
\text { - Compliance with pollution laws and regulations } \\
\text { - Compliance with health and safety standards and regulations } \\
\text { - Compliance status with the environmental and/or health and safety standards such as ISO, EMAS, BS OHSAS and PAS }\end{array}$ \\
\hline G3 & 1.3 Any awards related to the environment \\
\hline G4 & 1.4 Any general environmental accident \\
\hline E1 & 2.1 Greenhouse gases emissions \\
\hline E2 & 2.2 Any other significant air emissions \\
\hline E3 & 2.3 Actions to reduce the emissions \\
\hline E4 & 2.4 Waste and disposal methods \\
\hline E5 & 2.5 Information related to recycle or reducing the waste \\
\hline E6 & 2.6 Information related to any spills \\
\hline 3 & Sustainability \\
\hline S1 & 3.1 Any mention of sustainability \\
\hline S2 & 3.2 Any mention of sustainable development \\
\hline S3 & 3.3 Energy consumption and any efforts to reduce energy consumption \\
\hline S4 & 3.4 Any undertaking environmental impact studies to monitor the company's impact on the environment \\
\hline 4 & Products and Services \\
\hline PS1 & 4.1 Significant environmental impacts of products or transporting products and material used for the company's operations \\
\hline PS2 & 4.2 Pollution emissions and effluent discharges \\
\hline PS3 & 4.3 Efficient use of materials in the operations process \\
\hline PS4 & 4.4 Product safety \\
\hline PS5 & 4.5 Energy efficiency of products \\
\hline PS6 & 4.6 Packaging \\
\hline PS7 & 4.7 Recycling \\
\hline PS8 & 4.8 Initiatives to mitigate environmental impacts of products, activities and services \\
\hline 5 & Materials \\
\hline M1 & 5.1 Disclosures related to the used material \\
\hline M2 & 5.2 Disclosure related to the recycle material \\
\hline 6 & Water \\
\hline W1 & 6.1 Discharged or used water \\
\hline W2 & 6.2 Any information related to the recycle material \\
\hline 7 & Biodiversity and land \\
\hline B1 & 7.1 Location and size of land owned, leased and used \\
\hline B2 & 7.2 Land reclamation or reforestation \\
\hline B3 & 7.3 Biodiversity conservation \\
\hline B4 & 7.4 Any information related to biodiversity \\
\hline 8 & Environmental Auditing \\
\hline A1 & 8.1 Internal and/or external verification, review, scoping, audit and assessment of environmental performance and/or environmental disclosure \\
\hline 9 & Other Environmentally-Related Information \\
\hline 01 & 9.1 Environmental education and training \\
\hline $\mathrm{O} 2$ & 9.2 Environmental actions/lawsuits against the company \\
\hline $\mathrm{O} 3$ & 9.3 Environmental protection e.g. pest control \\
\hline O4 & 9.4 Any other environmental disclosure not fitting the categories above \\
\hline
\end{tabular}

\section{Fig. 2: Environmental Disclosure Checklist}




\begin{tabular}{|c|c|}
\hline \multicolumn{2}{|r|}{ GHG Emissions Checklist } \\
\hline No. & Categories \\
\hline 1 & Climate Change Risks and Opportunities \\
\hline $\mathrm{CC} 1$ & $\begin{array}{l}\text { Assessment/description of the risks (regulatory, physical or general) relating to climate change and actions taken or } \\
\text { to be taken to manage the risks }\end{array}$ \\
\hline $\mathrm{CC} 2$ & $\begin{array}{l}\text { Assessment/description of current (and future) financial implications, business implications and opportunities of } \\
\text { climate change }\end{array}$ \\
\hline 2 & GHG Emissions \\
\hline GHG1 & Description of the methodology used to calculate GHG emissions (e.g. GHG protocol or ISO) \\
\hline GHG2 & Existence external verification of quantity of GHG emission- if so by whom and on what basis \\
\hline GHG3 & Total GHG Emissions - metric tons CO2-e emitted \\
\hline GHG4 & Disclosure of scopes 1 and 2, or scope direct GHG emissions \\
\hline GHG5 & GHG5- Disclosure of GHG emissions by sources (e.g. coal, electricity, etc.) \\
\hline GHG6 & Disclosure of GHG emissions by facility or segment level \\
\hline GHG7 & Comparison of GHG emissions with previous years \\
\hline 3 & Energy Consumption \\
\hline EC1 & Total energy consumed (e.g. tera-joules or peta-joules) \\
\hline $\mathrm{EC2}$ & Quantification of energy used from renewable sources \\
\hline EC3 & Disclosure by type, facility or segment \\
\hline 4 & GHG Reduction and Cost \\
\hline $\mathrm{RC1}$ & Detail of plans or strategies to reduce GHG emissions \\
\hline $\mathrm{RC2}$ & Specification of GHG emissions reduction target level and target year \\
\hline $\mathrm{RC3}$ & Emissions reductions and associated costs or savings \\
\hline $\mathrm{RC4}$ & Cost of future emissions factored into capital expenditure planning \\
\hline 5 & Carbon Emissions Accountability \\
\hline AEC1 & $\begin{array}{l}\text { Indication of which board committee (or other executive body) has overall responsibility for actions related to } \\
\text { climate change }\end{array}$ \\
\hline AEC2 & $\begin{array}{l}\text { Description of the mechanism by which the board (or other executive body) reviews the company's progress } \\
\text { regarding climate change }\end{array}$ \\
\hline
\end{tabular}

Fig. 3: GHG Emissions Disclosure Checklist

\begin{tabular}{|c|c|l|}
\hline \multicolumn{3}{|l|}{ Pollution Disclosure } \\
\hline No. & Code & \multicolumn{1}{|c|}{ Items } \\
\hline 1 & P1 & Statements indicating that the company's operations are compliance with pollution laws and regulations \\
\hline 2 & P2 & Pollution control in the conduct of business operations \\
\hline 3 & P3 & Statements indicating that pollution from operations has been or will be reduced \\
\hline 4 & P4 & Disclosing water discharge information \\
\hline 5 & P5 & Disclosing air emissions or pollution information \\
\hline 6 & P6 & Disclosing solid waste disposal information \\
\hline 7 & P7 & Training and exercise for employees to engage in pollution management programs \\
\hline 8 & P8 & Noise pollution \\
\hline 9 & P9 & Biological hazards \\
\hline 10 & P10 & Investment in ecofriendly facilities \\
\hline 11 & P11 & Environmental pollution control facilities expenditures \\
\hline 12 & P12 & Fines / penalties / litigation on pollution \\
\hline 13 & P13 & Other contamination and remediation efforts \\
\hline 14 & P14 & Spills related information \\
\hline 15 & P15 & Other pollution related information \\
\hline
\end{tabular}


INTERNATIONAL JOURNAL OF ACADEMIC RESEARCH IN BUSINESS AND SOCIAL SCIENCES

Vol. 9, No. 3, March, 2019, E-ISSN: 222 2-6990 @ 2019 HRMARS

Fig. 4: Pollution Disclosure Checklist

\begin{tabular}{|c|c|c|c|}
\hline $\begin{array}{c}\text { Independent } \\
\text { Variable }\end{array}$ & $\begin{array}{c}\text { Definition of } \\
\text { Variable }\end{array}$ & $\begin{array}{l}\text { Quantification } \\
\text { System }\end{array}$ & Adopted from \\
\hline $\begin{array}{l}\text { The existence of } \\
\text { environmental } \\
\text { committee }\end{array}$ & $\begin{array}{l}\text { Total number of } \\
\text { environmental } \\
\text { committee within } \\
\text { the board }\end{array}$ & $\begin{array}{c}\text { Number of } \\
\text { environmental } \\
\text { committee in the } \\
\text { board: } \\
1-2=\text { Code as } 1 \\
3-4=\text { Code as } 2 \\
5-6=\text { Code as } 3 \\
>6=\text { Code as } 4\end{array}$ & Elsayih (2015) \\
\hline Board size & $\begin{array}{l}\text { Total number of } \\
\text { directors within } \\
\text { the board }\end{array}$ & $\begin{array}{c}\text { The total number } \\
\text { of board members } \\
1-7=\text { Code as } 0 \\
7-11=\text { Code as } 1 \\
>12=\text { Code as } 2\end{array}$ & $\begin{array}{l}\text { Htay, Abd. Rashid, } \\
\text { Adnan \& Meera } \\
\qquad(2012) \\
\text { Shamugam (2017) }\end{array}$ \\
\hline
\end{tabular}

Fig. 5: Description of the corporate governance as the independent variable

\section{Conclusion}

In conclusion, it is expected from the findings of this study to show a significant relationship between environmental performance and corporate governance towards the environmental disclosure of oil and gas companies operating in Malaysia upstream projects. Another area of GRI disclosure which was not being focused before is expected to be discovered from this study. The expected results from this study will help and contribute to the companies in improvising their practices for environmental disclosure.

\section{Acknowledgement}

The authors would like to express their gratitude to UCSI University Malaysia in enabling the research to be conducted and hence facilitating the write-up of this paper.

\section{Corresponding Author}

Safarina Abdul Ghani*

Faculty of Business \& Information Science, UCSI University, Terengganu Campus, 21600 Marang, Terengganu, MALAYSIA

Email: rinaghani@gmail.com 
INTERNATIONAL JOURNAL OF ACADEMIC RESEARCH IN BUSINESS AND SOCIAL SCIENCES

Vol. 9, No. 3, March, 2019, E-ISSN: 222 2-6990 @ 2019 HRMARS

\section{References}

Alonso-Almeida, M. D., Llach, J., \& Marimon, F. (2013). A Closer Look at the 'Global Reporting Initiative' Sustainability Reporting as a Tool to Implement Environmental and Social Policies: A Worldwide Sector Analysis. Corporate Social Responsibility Environmental Management, 21(6), 318-335.

Association of Chartered Certified Accountants (ACCA) \& Corporate Register.com. (2004). Towards Transparency: Progress on Global Sustainability Reporting. London: Corporate Register.

Bae Choi, B., Lee, D., \& Psaros, J. (2013). An analysis of Australian company carbon emission disclosures. Pacific Accounting Review, 25(1), 58-79. doi:10.1108/01140581311318968

Bewley, K., \& Li, Y. (2000). Disclosure of Environmental Information by Canadian Manufacturing Companies: A Voluntary Disclosure Perspective. Advances in Environmental Accounting and Management, 1, 201-226. doi:10.1016/S1479-3598(00)01011-6

Bonn, I. (2004). Effects of board structure on firm performance: A comparison of Japan and Australia. Asian Business and Management, 3(1), 105-125.

Braam, G. J., de Weerd, L. U., Hauck , M., \& Huijbregts, M. A. (2015). Determinants of corporate environmental reporting: the importance of environmental performance and assurance. Journal of Cleaner Production(129), 724-734.

Brammer , S. J., \& Pavelin, S. (2006). Corporate Reputation and Social Performance: The Importance of Fit. Journal of Management Studies, 43(3), 435-455.

Brown, N., \& Deegan, C. (1998). The public disclosure of environmental performance informationa dual test of media agenda setting theory and legitimacy theory. Accounting and Business Research, 29, 21-41.

Cheng, \& Shijun. (2008). Board size and the variability of corporate performance. Journal of Financial Economics, 87(1), 157-176.

Cheng, E. C., \& Courtenay, S. M. (2006). Board composition, regulatory regime and voluntary disclosure. The International Journal of Accounting, 41(3), 262-289.

Cho, C. H., Michelon, G., \& Patten, D. M. (2012). Impression Management in Sustainability Reports: An Empirical Investigation of the Use of Graphs. Accounting and the Public Interest, 12(1), 16-37. doi:10.2308/apin-10249

Cho, C. H., Roberts, R. W., \& Patten, D. M. (2010). The Language of US Corporate Environmental Disclosure. Accounting, Organizations and Society, 35(4), 431-443. doi:10.1016/j.aos.2009.10.002

Clarkson, P. M., Li, Y., Richardson, G. D., \& Vasvari, F. P. (2008). Revisiting the relation between environmental performance and environmental disclosure: An empirical analysis. Accounting, Organizations and Society, 33(4-5), 303-327.

Cuesta, M. d., \& Valor, C. (2013). Evaluation of the environmental, social and governance information disclosed by Spanish listed companies. Social Responsibility Journal, 9(2), 220240. doi:10.1108/SRJ-08-2011-0065

da Rosa, D. S., Lunkes, D. J., Hein, D., Vogt, M., \& Degenhart, L. (2014). Analysis of the determinants of disclosure of environmental impacts of Brazilian companies. Global Advanced Research Journal of Management and Business Studies, 3(6), 249-266. 
INTERNATIONAL JOURNAL OF ACADEMIC RESEARCH IN BUSINESS AND SOCIAL SCIENCES

Vol. 9, No. 3, March, 2019, E-ISSN: 222 2-6990 @ 2019 HRMARS

Dye, R. A. (1985). Disclosure of Nonproprietary Information. Journal of Accounting Research, 23(1), 123-145. doi:10.2307/2490910

Eljayash, K. M., James, D., \& Kong, D. (2012). The Quantity and Quality of Environmental Disclosure in Annual Reports of National Oil and Gas Companies in Middle East and North Africa. International Journal of Economics and Finance, 4(10), 201-217. doi:10.5539/ijef.v4n10p201

Elsayih, J. O. (2015). Corporate Governance and Carbon Performance and Disclosure: Australian Experience. Accounting Research Journal, 31(3), 405-422. doi:10.1108/ARJ-12-2015-0153

Eltaib, E. E. (2012). Environmental accounting disclosures of Australian Oil and Gas Companies. University of Wollongong Thesis Collection: Master of Accounting - Research Thesis, School of Accounting and Finance.

Gummerus, C. (2015). Evaluating Environmental Performance of Three Finnish Companies. Thesis Centria University of Applied Sciences, Degree Programme of Business Management.

Halme, M., \& Huse, M. (1997). The influence of corporate governance, industry and country factors on environmental reporting. Scandinavian Journal of Management, 13(2), 137-157. doi:10.1016/S0956-5221(97)00002-X

Htay, S. N., Ab.Rashid, H. M., Adnan, M. A., \& Mydin Meera, A. K. (2012). Impact of Corporate Governance on Social and Enviromental Information Disclosure of Malaysian Listed Banks: Panel Data Analysis. Asian Journal of Finance \& Accounting, 4(1), 1-24.

latridis, G. E. (2012). Environmental disclosure quality: Evidence on environmental performance, corporate governance and value relevance. Emerging Markets Review, 55-75.

Ionel-Alina, I., Emila, P. I., \& Mariaa, I. N. (2012). Environmental Reporting and Good Practice of Corporate. Procedia Economics and Finance,, 3, 961 - 967.

Jeswani, H. K., Wehrmeyer, W., \& Mulugetta, Y. (2008). How warm is the corporate response to climate change? Evidence from Pakistan and the UK. Business Strategy and the Environment, 17(1), 46-60. doi:10.1002/bse.569

Jitaree, W. (2015). Corporate social responsibility disclosure and financial performance: evidence from Thailand. University of Wollongong, Doctor of Philosophy thesis, School of Accounting, Economics and Finance.

Lakhal, F. (2005). Voluntary Earnings Disclosures and Corporate Governance: Evidence from France. Review of Accounting and Finance, 4(3), 64-85. doi:10.1108/eb043431

Laksmana, I. (2010). Corporate Board Governance and Voluntary Disclosure of Executive Compensation Practices. Contemporary Accounting Research, 25(4), 1147-1182.

Liu, Y., Zhou, Z., Zhang, X., Xu, X., Chen, H., \& Xiong, Z. (2015). Net global warming potential and greenhouse gas intensity from the double rice system with integrated soil-crop system management: A three-year field study. Biogeosciences Discuss, 12, 18883-18911.

Luo, L., \& Tang, Q. (2014). Does voluntary carbon disclosure reflect underlying carbon performance? Journal of Contemporary Accounting and Economics, 10(3), 191-205.

Mariano, J. B., \& La Rovere, E. L. (2007). Environmental impacts of the oil industry. Petroleum Engineering - Downstream.

Massie, R. K. (2001). Reporting on sustainability: A global initiative. OECD Observer No 226/227. Retrieved from OECD Observer: 
INTERNATIONAL JOURNAL OF ACADEMIC RESEARCH IN BUSINESS AND SOCIAL SCIENCES

Vol. 9, No. 3, March, 2019, E-ISSN: 222 2-6990 @ 2019 HRMARS

http://oecdobserver.org/news/archivestory.php/aid/493/Reporting_on_sustainability:_a_gl obal_initiative.html

Meng, X., Zeng, S., Shi, J. J., Qi, G., \& Zhang, Z. (2014). The relationship between corporate environmental performance and environmental disclosure: An empirical study in China. Journal of Environmental Management, 145, 357-367. doi: 10.1016/j.jenvman.2014.07.009

Milne, M. J., \& Patten, D. M. (2002). Securing organizational legitimacy: An experimental decision case examining the impact of environmental disclosures. Accounting, Auditing \& Accountability Journal, 15(3), 372-405.

Mobus, J. L. (2005). Mandatory environmental disclosures in a legitimacy theory context. Journal of Business Ethics, 79(3), 245-262.

Murcia, F. D.-R., \& Santos, A. d. (2012). Discretionary-Based Disclosure: Evidence from the Brazilian Market. Brazilian Administration Review, 9(1), 88-109.

Noronha, C., Tou, S., Cynthia, M., \& Guan, J. J. (2012). Corporate Social Responsibility Reporting in China: An Overview and Comparison with Major Trends. Corporate Social Responsibility and Environmental Management, 20(1), 29-42. doi:10.1002/csr.1276

Patten, D. M. (2002). The relation between environmental performance and environmental disclosure: a research note. Accounting, Organizations and Society, 27(8), 763-773.

Peters, G. F., \& Romi, A. M. (2015). The Association between Sustainability Governance Characteristics and the Assurance of Corporate Sustainability Reports. 34(1), 163-198. doi:10.2308/ajpt-50849

Rao, K. K., Tilt, C. A., \& Lester, L. H. (2012). Corporate governance and environmentalreporting: an Australian study. Corporate Governance, 12(2), 143-163.

Shamugam, S. (2017). The Relationship Between Corporate Governance Quality and Sustainability Reporting: An analysis of Top Performing Companies and Financially Distressed Companies. Doctoral Dissertation, Auckland University of Technology.

Solomon, J. (2013). Corporate Governance and Accountability (4th ed.). Wiley.

Stern, N. (2006). What is the Economics of Climate Change? World Economics, 7(2). Retrieved from https://www.humphreyfellowship.org/system/files/stern_summary__what_is_the_econo mics_of_climate_change.pdf

Sulaiman, M., Abdullah, N., \& Fatima, A. (2014). Determinants of Environmental Reporting Quality in Malaysia. International Journal of Economics, Management and Accounting, 22(1), 63-90.

Sustainability Reporting. (2018). Retrieved from Globalreporting.org: https://www.globalreporting.org/information/sustainability-reporting/Pages/default.aspx

Sustainability reporting in Malaysia: which framework to choose? (2017). Retrieved from Malaysiaplc.com: http://www.malaysiaplc.com/articles/sustainability/sustainabilityreporting-in-malaysia-which-framework-to-choose/

(2016). The Malaysian Oil \& Gas Industry - Challenging times, but fundamentals intact. PricewaterhouseCoopers (PwC) Malaysia.

Verrechia, R. E. (1983). Discretionary disclosure. Journal of Accounting and Economics, 5, 179-194. doi:10.1016/0165-4101(83)90011-3 
INTERNATIONAL JOURNAL OF ACADEMIC RESEARCH IN BUSINESS AND SOCIAL SCIENCES

Vol. 9, No. 3, March, 2019, E-ISSN: 222 2-6990 @ 2019 HRMARS

Xie, B., Davidson III, W. N., \& DaDalt, P. J. (2003). Earnings management and corporate governance:the role of the board and the audit committee. Journal of Corporate Finance, 9(3), 295-316. 